\title{
Motivation Interview Effectiveness and Optimism Efficiency on the Quality of Life of Type 2 Diabetes Mellitus
}

\author{
Ridwan Amiruddin ${ }^{1}$, Nurhaedar $\operatorname{Jafar}^{2}$ (D) Jumriani Ansar ${ }^{1}$ (D), Zhanaz Tasya ${ }^{3 *}$ (D) \\ ${ }^{1}$ Department of Epidemiology, Faculty of Public Health, Hasanuddin University, City of Makassar, Indonesia; ${ }^{2}$ Department of \\ Nutrition, Faculty of Public Health, Hasanuddin University, City of Makassar, Indonesia; ${ }^{3}$ Department of Epidemiology, Faculty \\ of Public Health, Universitas Muhammadiyah Palu, City of Palu, Indonesia
}

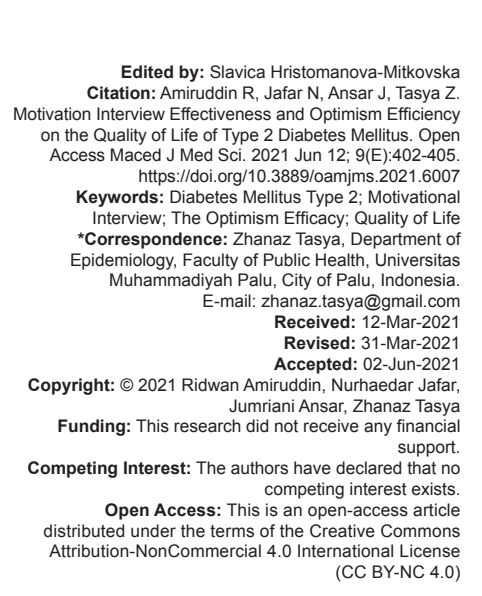

\section{Abstract}

AIM: This study aims to analyze the quality of life of people with type 2 diabetes mellitus (T2DM) through the intervention of motivational interview and efficacy of optimism.

METHODS: The type of research is Quasi Experimental - Non-Randomized Control Group Pretest Posttest Design. The sample was T2DM patients, while the treatment was carried out on 50 respondents. Interventions were given in motivational interviews and the effectiveness of optimism. The statistical test used is the two-dependent difference test and two independent mean difference test.

RESULTS: The statistical test of the difference between the two independent means showed the sig. value (two tailed) of 0.006 . It pointed to a significant difference in post-test between DM patients' quality of life in the intervention and control groups. Based on the two dependent difference test, the mean showed that the value of sig. (two tailed) 0.000 means a significant difference between DM patients' quality of life in the intervention and control groups after the post-test.

CONCLUSION: There was a substantial relationship between motivational interviewing and optimism efficacy on the quality of diabetes mellitus patients.

\section{Introduction}

The World Health Organization analysis results for the period of 2012-2030, Indonesia will be burdened with IDR 2800 trillion due to diabetes, or the equivalent of 20 times Indonesia's 2012 health budget as a whole [1]. Indonesia will also experience a significant workforce loss due to diabetes mellitus. It may result in a much more substantial decline in its production capacity than other Asian countries. On the other hand, the demographic will be meaningless for Indonesia's economic development. Indonesia will be increasingly left behind from other countries in Asia due to a considerable reduction in its production capacity due to available labor in sick conditions [2]. Basic Health Research of Indonesia (Riskesdas) Data shows that the prevalence of diabetes mellitus in Indonesia is relatively high, increasing from $6.9 \%$ in 2013 to $8.5 \%$ in 2018 [3], [4].

Research conducted by researchers was related to various risk factors for type 2 diabetes mellitus (T2DM) including central obesity $(p=0.000)$, consumption of vegetables and fruits $(p=0.000)$, physical activity $(p=0.03)$, smoking $(p=0.00)$, and stress $(p=0.00)$ [5]. Likewise, research on risk factors for fiber consumption have odds ratios $(\mathrm{OR})=2.355$ and diet history OR 2.35 for type 2 diabetes mellitus; the conclusion of this study also shows that fiber and coffee consumption significantly affect the increase in the incidence of diabetes [6]. Based on data from the Health Agency of South Sulawesi Province, the death rate for diabetes mellitus in the health center in 2010 was $10.30 \%$, in 2011 , it was $11.26 \%$, and in 2012 , it was 232 cases. South Sulawesi Province is one of the provinces with quite a lot of diabetes mellitus patients. It is a public health problem because although efforts have been made to control the four pillars. Those are including education, meal planning, exercise, and pharmacological interventions, the number of patients has not decreased. Diabetes mellitus-related deaths in South Sulawesi province also contribute to important health problems [7].

The study aimed to analyze the quality of life among people with T2DM with motivational interviews and optimism efficacy. 


\section{Methods}

\section{Data sources}

This study used secondary data obtained from the Health Office of South Sulawesi Province and PT. Medical record data at Health Centre (Puskesmas) of Pattingalloang and Galesong, Makassar City, South Sulawesi Province, and primary data sourced from interviews with respondents.

\section{Populations and samples}

This research was conducted in the working area of Puskesmas Pattingalloang Makassar and Puskesmas Galesong Utara Takalar, as a coastal area with a high prevalence rate of T2DM. The population in this study were all T2DM patients. The sample size in this study was 50 patients with T2DM. The inclusion criteria in this study were as follows: (1) T2DM patients who have medical records at Puskesmas Pattingalloang; (2) patients aged $\geq 18$ years and routinely followed the interventions given (at least once absent); and (3) willing to be a respondent volunteer.

\section{Data analysis}

Data analysis included univariate analysis and bivariate analysis using SPSS.

\section{Quality control}

Quality control was intended to supervise all stages of the measurement process to achieve valid and consistent results. Thus, the research results were close to reality and obtained a good theory for scientific studies to reduce scientific errors.

\section{Ethic}

This research was equipped with an ethical clearance issued by the Commission of Ethics of the Hasanuddin University Faculty of Public Health. It was used for the respondent's security and confidentiality study. With ethical approval No: 5248/UN4.14/ KA.04.01/2019 on July 30, 2019, by the Chairman of the Commission Ethics Board, Prof. Dr. Veni Hadju.

\section{Results}

Table 1 shows that most of the respondents were aged $35-55$ years, about $68 \%$ in the intervention group and $52 \%$ in the control group. The gender of the respondents, in general, was women and married. Furthermore, the education level of respondents generally was primary school education and worked as a housewife. Regarding insulin use, most of the respondents did not use insulin, was $76 \%$ in the intervention and control groups.

Table 1: Characteristics of respondents

\begin{tabular}{|c|c|c|c|c|c|c|}
\hline \multirow[t]{2}{*}{ Characteristics } & \multicolumn{2}{|c|}{ Intervention } & \multicolumn{2}{|c|}{ Control } & \multirow[t]{2}{*}{$\mathrm{n}$} & \multirow[t]{2}{*}{$\%$} \\
\hline & $\mathrm{n}$ & $\%$ & $\mathrm{n}$ & $\%$ & & \\
\hline \multicolumn{7}{|l|}{ Age group (years) } \\
\hline $35-55$ & 17 & 68 & 13 & 52 & 30 & 60 \\
\hline $56-75$ & 8 & 32 & 12 & 48 & 20 & 40 \\
\hline \multicolumn{7}{|l|}{ Sex } \\
\hline Male & 6 & 24 & 6 & 24 & 12 & 24 \\
\hline Female & 19 & 76 & 19 & 76 & 38 & 76 \\
\hline \multicolumn{7}{|l|}{ Marital status } \\
\hline Single & 17 & 68 & 18 & 72 & 35 & 70 \\
\hline Widower & 8 & 32 & 7 & 28 & 15 & 30 \\
\hline \multicolumn{7}{|l|}{ Education } \\
\hline Not elementary school & 13 & 52 & 8 & 32 & 21 & 42 \\
\hline Elementary school & 7 & 28 & 10 & 40 & 17 & 34 \\
\hline Junior high school & 2 & 8 & 5 & 20 & 7 & 14 \\
\hline Senior high school & 2 & 8 & 2 & 8 & 4 & 8 \\
\hline Diploma & 1 & 4 & 0 & 0 & 1 & 2 \\
\hline \multicolumn{7}{|l|}{ Profession } \\
\hline Entrepreneur & 4 & 16 & 5 & 20 & 9 & 18 \\
\hline Farmer & 0 & 0 & 1 & 4 & 1 & 2 \\
\hline Fisherman & 2 & 8 & 1 & 4 & 3 & 6 \\
\hline Housewife & 18 & 72 & 18 & 72 & 36 & 72 \\
\hline Others & 1 & 4 & 0 & 0 & 1 & 2 \\
\hline \multicolumn{7}{|l|}{ Use of insulin } \\
\hline Yes & 6 & 24 & 6 & 24 & 12 & 24 \\
\hline No & 19 & 76 & 19 & 76 & 38 & 76 \\
\hline
\end{tabular}

Table 2 shows the quality of life before the intervention in patients with diabetes mellitus. The highest intervention group had an average quality of life of $56 \%$ and had a poor quality of life of $55 \%$ in the control group. After the intervention showed the quality of life of DM patients, the highest intervention group obtained a good quality of life by $69 \%$ and in the control group with a good quality of life by $45 \%$.

Table 2: Quality of life of people with T2DM before and after the intervention

\begin{tabular}{|c|c|c|c|c|c|c|}
\hline \multirow[t]{2}{*}{ Variable } & \multicolumn{2}{|c|}{ Intervention } & \multicolumn{2}{|c|}{ Control } & \multirow[t]{2}{*}{$\mathrm{n}$} & \multirow[t]{2}{*}{$\%$} \\
\hline & $\mathrm{n}$ & $\%$ & $\mathrm{n}$ & $\%$ & & \\
\hline \multicolumn{7}{|c|}{ Quality of life (pre-test) 1} \\
\hline Poor & 5 & 31 & 6 & 55 & 11 & 41 \\
\hline Average & 9 & 56 & 3 & 27 & 12 & 44 \\
\hline Good & 2 & 13 & 2 & 18 & 4 & 15 \\
\hline \multicolumn{7}{|c|}{ Quality of life (post-test) } \\
\hline Poor & 0 & 0 & 2 & 18 & 2 & 7 \\
\hline Average & 2 & 13 & 4 & 36 & 6 & 22 \\
\hline Good & 11 & 69 & 5 & 45 & 16 & 59 \\
\hline Very good & 3 & 19 & 0 & 0 & 3 & 11 \\
\hline
\end{tabular}

Table 3 shows the sig. (two tailed) for the education (0.000), there was a significant difference between DM patients' quality of life in the intervention and control groups. For the sig. (two tailed) work was 0.076 , and there was no significant difference between the quality of life of DM patients in the intervention group and the control group in terms of employment.

Table 3: The relationship between education and work on quality of life for people with T2DM

\begin{tabular}{lllll}
\hline Variable & Mean & Std. deviation & $95 \% \mathrm{Cl}((\mathrm{LL}-\mathrm{UL})$ & $\mathrm{p}$ \\
\hline Education & -1.704 & 1.171 & $-2.167-(-1.241)$ & 0.000 \\
Profession & 0.444 & 1.251 & $-0.050-0.939$ & 0.076 \\
\hline
\end{tabular}

Table 4 shows the sig. (two tailed) of 0.006 , a significant difference between the DM patient's quality of life in intervention and control groups after the intervention. Then, the statistical test between the intervention group and the control showed the 
sig value (two tailed) of 0.000 , there is a significant difference between the quality of life of DM patients in the intervention group and the control group after the intervention motivation interview.

Table 4: Statistical results

\begin{tabular}{|c|c|c|c|c|c|}
\hline \multirow{2}{*}{$\begin{array}{l}\text { Variable } \\
\text { Quality of life T2DM (Pre-test) }\end{array}$} & \multirow[t]{2}{*}{ Mean } & \multicolumn{2}{|c|}{ Std. deviation } & \multirow[t]{2}{*}{$95 \% \mathrm{Cl}(\mathrm{LL}-\mathrm{UL})$} & \multirow[t]{2}{*}{$p$} \\
\hline & & & & & \\
\hline Intervention & 2.81 & 0.655 & \multicolumn{2}{|c|}{$-0.405-0.757$} & 0.538 \\
\hline Control & 2.64 & 0.809 & \multicolumn{2}{|c|}{$-0.440-0.792$} & \\
\hline \multicolumn{6}{|l|}{ Quality of life T2DM (Post-test) 1} \\
\hline Intervention & 4.06 & 0.574 & \multicolumn{2}{|c|}{$-0.252-1.328$} & 0.006 \\
\hline Control & 3.27 & 0.786 & \multicolumn{2}{|c|}{$-0.206-1.374$} & \\
\hline Quality of life T2DM (Pre-test) & 2.74 & 0.712 & \multirow{2}{*}{\multicolumn{2}{|c|}{$-1.269-0.731$}} & 0.000 \\
\hline Quality of life T2DM (Post-test) & 3.74 & 0.764 & & & \\
\hline
\end{tabular}

Table 5 shows the sig. (two tailed) of 0.002 . There was a significant difference between the quality of life of DM patients in the intervention group and the control group before and after the DM exercise intervention.

Table 5: Relationship of DM exercise with the quality of life of patients with DM

\begin{tabular}{lllll}
\hline Variable & Mean & Std. deviation & $95 \% \mathrm{Cl}(\mathrm{LL}-\mathrm{UL})$ & $\mathrm{p}$ \\
\hline Quality of life T2DM (Pre-test) & -0.704 & 1.068 & $-1.126-0.281$ & 0.002 \\
Quality of life T2DM (Post-test) & 1.444 & 1.450 & & \\
\hline
\end{tabular}

\section{Discussion}

Quality of life is defined as a person's subjective perception of the physical, environmental, social, and psychological conditions they experience. According to Coons and Kaplan, everyone has a various quality of life depending on each individual in addressing the problems that occur in him. If the problem is faced positively, the quality of life will be good. However, if the problem is faced negatively, the quality of life will also be bad [8], [9], [10]. This study indicated that people with diabetes mellitus before the intervention in the intervention group had a moderate quality of life $(56 \%)$ and the control group had a poor quality of life by $55 \%$. The quality of life of post-intervention diabetes mellitus patients in the intervention group had the highest quality of life by $69 \%$. The control group had a good quality of life by $45 \%$. The aspects assessed from the socioculture in this study are education and employment. Education is an important factor that diabetes mellitus patients need because education is an indicator of patient understanding of care, self-management, and control of glucose levels [11], [12]. The openness of diabetes mellitus patients to health information will lead patients to carry out healthy lifestyle behaviors that lead to a better quality of life. Blood glucose levels can be controlled, and the patient's health status will remain stable [13].

This study indicated a significant difference $(p=0.006)$ between the quality of life of the intervention and control groups in terms of education. There was no significant difference between the intervention group's quality of life and the control group in terms of work $(p=0.076)$. The previous research also showed an increase in the mean value of quality of life in the social relationship domain of T2DM patients at Puskesmas Pattingalloang (intervention group) after a motivational interview program intervention [14]. Motivational interviewing is clientdirected and client-centered counseling to elicit behavior change by helping patients explore and resolve disease problems [15]. Meanwhile, self-efficacy is an individual's belief in organizing and carrying out the tasks needed to get the expected results. Self-efficacy comes from individual experiences, experiences of other people, social persuasion, and physical and emotional conditions [16].

Besides, self-efficacy can be formed and developed through four processes, namely, cognitive, motivational, affective, and selection. Nursing interventions to improve patient self-efficacy can be carried out through a four-source approach and a selfefficacy process [17], [18]. The government works with health-care providers to design programs integrated with a chronic disease management model for participants suffering from chronic diseases, including diabetes mellitus. It is known well as the "Chronic Disease Management Program." This program uses a proactive approach implemented in an integrative manner by actively involving participants to achieve an optimal life quality [19]. This activity is actively carried out every Saturday at Puskesmas Pattingalloang and Galesong Utara. Activities carried out include exercise, group education, motivational interviews, health consultations or sharing of experiences between participants, medical examinations by doctors, blood sugar checks and medication, and diabetes mellitus exercises.

This study indicated a significant difference between people's quality of life with diabetes mellitus in the intervention and control groups after the intervention $(p=0.000)$. There was a considerable difference between people's quality of life with diabetes mellitus in the intervention and control groups after the intervention $(p=0.000)$. The same was found in diabetes mellitus patients in the intervention and control groups after diabetes mellitus exercise intervention $(p=0.002)$. This study is in line with research that shows a significant relationship between diabetes mellitus exercise and the quality of life for T2DM patients [20].

\section{Conclusion}

A significant relationship was found between motivational interviewing and optimism efficacy on the quality of diabetes mellitus patients.

\section{Acknowledgments}

The author would like to thank the Directorate of Research and Community Service, Directorate 
General of Research and Development, Ministry of Research, Technology and Higher Education, Head of Puskesmas, and Head of Posbindu Makassar City Group.

\section{References}

1. World Health Organization. The Republic of Indonesia Health System Review. Vol. 7. Geneva: World Health Organization; 2017.

2. World Health Organization. Global Status Report on Noncommunicable Diseases. Geneva: World Health Organization; 2010. p. 176.

3. Kementerian Kesehatan RI. Basic Health Research. Kementerian Kesehatan RI; 2013.

4. Kementerian Kesehatan RI. Main Results of Riskesdas 2018. Kementerian Kesehatan RI; 2013.

5. Amiruddin R, Ansar J, Sidik D. Diabetic mellitus Type 2 in Wajo South Sulawesi, Indonesia. Int J Curr Res Acad Rev. 2014;2(12):1-8

6. Amiruddin R, Asrianti T, Abdullah MT. Fiber, coffee, cigarette and gestational diabetes mellitus in Makassar Indonesia. Asian J Epidemiol 2017;10:26-31. https://doi.org/10.3923/ aje.2017.26.31

7. DINKES. Profil Kesehatan Provinsi Sulawesi Selatan Tahun 2015. Profil Kesehat, Provinsi Sulawesi Selatan; 2015. p. 111. https://doi.org/10.26858/est.v1i3.1826

8. Almailabi M, Alajmi R, Balkhy A, Khalifa M, Mikwar Z, Khan M. Quality of life among surgical residents at king Abdulaziz medical city in Jeddah, Saudi Arabia. Open Access Maced J Med Sci. 2019;7(23):4163-7.

9. Post MW. Definitions of quality of life: What has happened and how to move on. Top Spinal Cord Inj Rehabil 2014;20:167-80. https://doi.org/10.1310/sci2003-167 PMid:25484563

10. Seymour $\mathrm{V}$. The human-nature relationship and its impact on health: A critical review. Front Public Health 2016;4:260. PMid:27917378

11. Powers MA, Bardsley J, Cypress M, Duker P, Funnell MM,
Fischl AH, et al. Diabetes self-management education and support in Type 2 diabetes: A joint position statement of the American Diabetes Association, the American Association of diabetes educators, and the Academy of nutrition and dietetics. Clin Diabetes 2016;34(2):70-80. https://doi.org/10.2337/diaclin.34.2.70 PMid:27092016

12. Lambrinou E, Hansen TB, Beulens JW. Lifestyle factors, self-management and patient empowerment in diabetes care. Eur J Prev Cardiol. 2019;26(Suppl 2):55-63. https://doi. org/10.1177/2047487319885455 PMid:31766913

13. Shrivastava SR, Shrivastava PS, Ramasamy J. Role of selfcare in management of diabetes mellitus. J Diabetes Metab Disord 2013;12(1):14. https://doi.org/10.1186/2251-6581-12-14 PMid:23497559

14. Limbong UB, Amiruddin R, Thaha RM. The influence of motivational interviewing and gymnastics on the quality of life of patients with Type 2 diabetes in pattingaloang health center. J Kesehatan Masyarakat Maritim. 2019;1(3):8827. https://doi. org/10.30597/jkmm.v1i3.8827

15. Al Ubaidi BA. Motivational interviewing skills: A tool for healthy behavioral changes. J Fam Med Dis Prev. 2017;3(4):1-5. https:// doi.org/10.23937/2469-5793/1510069

16. Chen X, Zhang G, Yin X, Li Y, Cao G, Gutiérrez-García C, et al. The relationship between self-efficacy and aggressive behavior in boxers: The mediating role of self-control. Front Psychol. 2019;10:212. https://doi.org/10.3389/fpsyg.2019.00212 PMid:30837910

17. Loeb C. Self-Efficacy at Work Self-Efficacy at Work Social, Emotional, and Cognitive Dimensions, No. 208; 2016.

18. Pinto S, Fumincelli L, Mazzo A, Caldeira S, Martins JC. Comfort, well-being and quality of life: Discussion of the differences and similarities among the concepts. Porto Biomed J 2017;2(1):612. https://doi.org/10.1016/j.pbj.2016.11.003 PMid:32258577

19. Social Security Administrator for Health. Panduan Praktis Prolanis (Program Pengelolaan Penyakit Kronis). Indonesia: BPJS Kesehat; 2014.

20. Myers VH, McVay MA, Brashear MM, Johannsen NM, Swift DL, Kramer K, et al. Exercise training and quality of life in individuals with Type 2 diabetes. Diabetes Care. 2013;36(7):1884-90. https://doi.org/10.2337/dc12-1153

PMid:23404304 